\title{
Consequences of Student Part-Time Employment (Case Study of Sebelas Maret University Student)
}

\author{
Hana Maharani Fahimah, Aniek Hindrayani, Jonet Ariyanto Nugroho \\ Universitas Sebelas Maret \\ hanamfahimah@gmail.com
}

\section{Article History}

accepted 31/01/2021

approved 28/02/2021

published 31/03/2021

\begin{abstract}
The aim of the paper is to examine the consequences of students engaging in part-time employment during their studies. The research consisted of a Google form survey of all the student of Sebelas Maret University, on 2015 and 2016 who studies also doing part-time. The survey found that part-time employment, in common with many previous studies. It also found that some students were spending longer in their chosen employment than in time-tabled classes. A central finding was that unlike much previous research, it emerged here that students reported more positive than negative outcomes to improve the student skills, but effect to the learning achievement give the negative outcomes. The data shows that students continue to engage in part-time employment at a significant level and for some studying is almost a secondary activity. The paper is of value in seeking to clarify the nature of the consequences for students seeking to combine employment and studying. Furthermore the paper builds on our understanding of the effect of part-time to the student learning achievement that gives negative effects but give the positive effect about the student skill to understand about business, social relationship, etc.
\end{abstract}

Keywords: Part-time employment, Part-time workers, Student experience, learning achievement

\begin{abstract}
Abstrak
Tujuan dari makalah ini adalah untuk meneliti konsekuensi dari siswa yang terlibat dalam pekerjaan paruh waktu selama masa studi mereka. Penelitian ini terdiri dari survei di Google Form terhadap seluruh mahasiswa Universitas Sebelas Maret tahun 2015 dan 2016 yang menempuh studi juga paruh waktu. Survei menunjukkan bahwa pekerjaan paruh waktu, yang sama dengan banyak studi sebelumnya. Ditemukan juga bahwa beberapa siswa menghabiskan waktu lebih lama dalam pekerjaan yang mereka pilih daripada di kelas yang diatur waktunya. Temuan utama adalah bahwa tidak seperti banyak penelitian sebelumnya, muncul di sini bahwa siswa melaporkan hasil yang lebih positif daripada negatif untuk meningkatkan keterampilan siswa, tetapi pengaruh terhadap prestasi belajar memberikan hasil yang negatif. Data menunjukkan bahwa siswa terus terlibat dalam pekerjaan paruh waktu pada tingkat yang signifikan dan untuk beberapa belajar hampir menjadi kegiatan sekunder.. . Makalah ini bernilai dalam upaya mengklarifikasi sifat konsekuensi bagi siswa yang ingin menggabungkan pekerjaan dan pembelajaran. Selanjutnya makalah ini dibangun berdasarkan pemahaman kita tentang pengaruh paruh waktu terhadap prestasi belajar siswa yang memberikan pengaruh negatif tetapi memberikan pengaruh positif tentang keterampilan siswa untuk memahami bisnis, hubungan sosial, dll.
\end{abstract}

Kata kunci: Pekerjaan paruh waktu, Pekerja paruh waktu, Pengalaman siswa, prestasi belajar

Social, Humanities, and Education Studies (SHEs): Conference Series https://jurnal.uns.ac.id/shes

p-ISSN 2620-9284

e-ISSN 2620-9292 


\section{INTRODUCTION}

An increasingly prominent feature of the higher education sector in the Indonesia is the rise in the number of students undergraduates, while working in part-time employment. This is not, however, a new phenomenon and part-time working has been a feature of the university experience for some time (Barron \& Anastasiadou, 2009). This means that term-time working is now a common place aspect of the undergraduate student experience (Curtis \& Shani, 2002). It has been suggested, however, that perhaps the notion of the full-time student is increasingly one that is no longer applicable (Moreau \& Leathwood, 2006). The aim of this paper is to examine the nature of students' part- time employment and to discuss the reported consequences of holding such employment during term time.

Student part-time employment has been receiving an increased level of interest from academic researchers since the early 1990s. A growing body of literature has investigated this phenomenon, with a view to establishing the nature of that employment, and the possible consequences for individuals seeking to combine study and employment. The participation of university students in the labor market during their studies is not a new development, however, and in some countries such activity is the norm rather than the exception. Research carried out in other countries indicates that the prevalence of part- time student employment continues to grow. In Germany student employment is a well- established phenomenon (Winkler, 2009). While the Euro student Survey (HIS, 2005) found term-time employment rates of 20 per cent in Portugal, 30 per cent in Italy, 69 per cent in Ireland and 91 per cent in the Netherlands.

Beyond Europe the statistics also indicate variations in the rate of employment across different countries. A large scale survey in Australia $\left(n^{1 / 434,752)}\right.$ found that 72.5 per cent of those who responded held a part-time job during term time (Long, Hayden, 2001). This figure marked an increase in student employment of more than 20 per cent since the survey was first commissioned in 1984. This growth in student part-time employment in Australia is supported by Salamonson and Andrew (Salamonson \& Andrew, 2006) in a survey of 267 nursing students. They found that more than three quarters of the students held a part-time job during their studies, working on average for 14 hours per week. A smaller scale survey at a single university in New Zealand $\left(\mathrm{n}^{1 / 483}\right)$ reported that 81 per cent held a part-time job during term time (Manthei \& Gilmore, 2005). Evidence from China indicates that some students are engaging in part-time employment during their studies. For example, Tam and Morrison (Oi I \& Morrison, 2005) found that 66.9 per cent of students held a part-time job in a survey

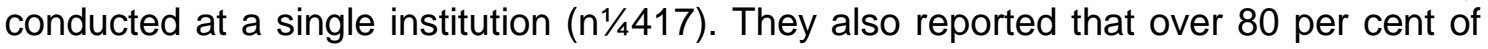
the sample found that, overall, working while studying was beneficial to their academic work. However, this prevalence of employment amongst higher education students is not reflected in all countries. In a study of 466 undergraduates in Greece, where there is no established tradition of students being engaged in employment, it was found that the majority did not work during term time (Mihail \& Karaliopoulou, 2005).

While the Student Living Report UNITE (UNITE, 2004) found that 39 per cent of students were working part time and 3 per cent were working full time during their studies. A note of caution is necessary, however, the cost of studies, and the increase in part-time student employment, is not a causal one and may be due to other factors (Metcalf, 2005). This is because levels of student employment are a function of the level of employment generally in the economy; the socio-demographic profile of students; the nature of the available financial support structure; and the amount of class contact time required by the course (Darmody \& Smyth, 2008). This view is 
supported by Ryland (Ryland, E., Riordan, R.J. and Brack, G, 1994) who argue that the relationship between students and their participation in the labor market is a complex one.

Broadbridge and Swanson (Broadbridge \& Swanson, 2005) are critical of the existing student employment literature and further weakness of existing studies is that so far they have failed to establish conclusively whether term-time employment is either a negative or a positive feature of the higher education sector. The contribution of this paper is in seeking to establish more clearly the consequences for individual students of attempting to combine student undergraduates with part-time employment. While some studies have reported benefits (time management, enhanced employability, improved social skills), there is a comparable number that reported negative outcomes (reduction in reading, missing time- tabled classes, tiredness). The overall aim of this paper is to build on the work of Ford and Bosworth (Ford et al., 1995) and (Moreau \& Leathwood, 2006), to clarify the nature of the relationship between term-time employment and studying in higher education.

\section{RESEARCH QUESTION}

Researchers also conducted several studies on the results of previous studies conducted by other researchers. As the results of research that the factor that make student undergraduate doing part-time were so many reason and caution is necessary, however, the cost of studies, and the increase in part-time student employment, is not a causal one and may be due to other factors (Metcalf, 2005). This is because levels of student employment are a function of the level of employment generally in the economy; the socio-demographic profile of students; the nature of the available financial support structure; and the amount of class contact time required by the course (Darmody \& Smyth, 2008). This view is supported by Ryland [13] who argue that the relationship between students and their participation in the labor market is a complex one.

Broadbridge and Swanson (Broadbridge \& Swanson, 2005) are critical of the existing student employment literature and further weakness of existing studies is that so far they have failed to establish conclusively whether term-time employment is either a negative or a positive feature of the higher education sector. The contribution of this paper is in seeking to establish more clearly the consequences for individual students of attempting to combine student undergraduates with part-time employment. While some studies have reported benefits (time management, enhanced employability, improved social skills), there is a comparable number that reported negative outcomes (reduction in reading, missing time- tabled classes, tiredness). The overall aim of this paper is to build on the work of Ford and Bosworth (Ford et al., 1995) and (Moreau \& Leathwood, 2006), to clarify the nature of the relationship between term-time employment and studying in higher education.

\section{METHODOLOGY}

\section{Design and sample}

Following a review of previous studies of student part-time employment, a selfreport questionnaire was developed based upon the key issues to emerge from the literature. A central issue from this review was the apparent ambiguity concerning whether holding part-time employment could be characterized as being desirable or undesirable. In particular the questionnaire design drew upon 
the survey work of (Curtis \& Shani, 2002), (Ford et al., 1995) and (Barke et al., $2000)$. This questionnaire was piloted on a small scale $(n=384$ student from all the faculty in UNS) within one school of the university. In light of data generated a revised version of the questionnaire was developed.

The aim of the questionnaire was to generate data concerning; the amount of time that students work in the week, the type of part-time employment among the university's undergraduate student population, students' motivation for engaging in part-time work, and the impact of holding part-time employment on students, with particular reference to their ability to cope with the demands of combining academic study and employment.

Section 1 of the questionnaire contained demographic questions concerning course of study, faculty, age, gender and ethnicity. The second section of the questionnaire focused on data about the type of any term-time employment held, the consequences of combining studying and part-time employment and the benefits obtained when student get a part-time job.

\section{Sample}

The study was carried out in Sebelas Maret University on 2015 and 2016 grade who get a part-time job. All of those invited to take part in the survey were undergraduate students. Each undergraduate student who get a part-time job was contacted meet in person to interview and ask some question, contacted via e-mail and invited to complete an online survey concerning part-time employment by Google form. The survey was completed by 384 students studying on Faculty of Engineering $(n=18)$, Faculty of Cultural Studies $(n=15)$, Faculty of art and Design $(n=12)$, Faculty of Economics and Business $(n=22)$, Faculty of Social and Political Sciences $(n=21)$, Faculty of Law $(n=19)$, Faculty of Teacher Training and Education $(n=165)$, Medical Faculty $(n=6)$, Faculty of Mathematics and Natural Education ( $n=57)$ and Faculty of Agriculture $(n=49)$.

The result of the gender in the sample with 68 per cent of respondents being female and 32 per cent male, although this is broadly representative of the student population for the institution as a whole, which is comprised of more female than male students. The result of the grade of the participants were grade 2015 with 74 per cent respondents and 26 per cent of grade 2016.

\section{RESULTS AND DISCUSSIONS}

\section{Working hours}

With regard to the number of hours worked, 40 per cent of the sample were working up to nine hours per week at their type job chosen employer, with 39 per cent working 10-24 hours per week, with 13 per cent of the sample were working 25-34 hours per week, with 6 per cent of the sample were working 35-44 hours per week and 2 per cent working 45-59 hours per week. However, many of the respondents in this survey did not have a consistent working pattern each week, and so any figure for average hours per week may mask important variations between students (Moreau \& Leathwood, 2006).

The issue of the length of time spent in employment is important due to the effect on a student's learning achievement has experienced a significant change namely a decrease in student learning achievement, form 3,57 to 3,48, although it has been suggested that it is the ability of the individual to manage their time effectively which is more important (Carney et al., 2005). Respondents were 
asked about the average number of class contact hours per week, with a reported average of 17.2 hours (www.ocw.uns.ac.id). This means that almost 50 per cent of the sample was working longer in their part-time work than they did in lectures and tutorials. A related issue is the relative importance that individuals place on their job in comparison to their degree studies. When asked the extent to which employment commitments were fitted around university commitments, the majority (60 per cent) answered that their study took priority.

The Grouping of UNS Undergraduate Students who Work Part-Time Based on The Faculty

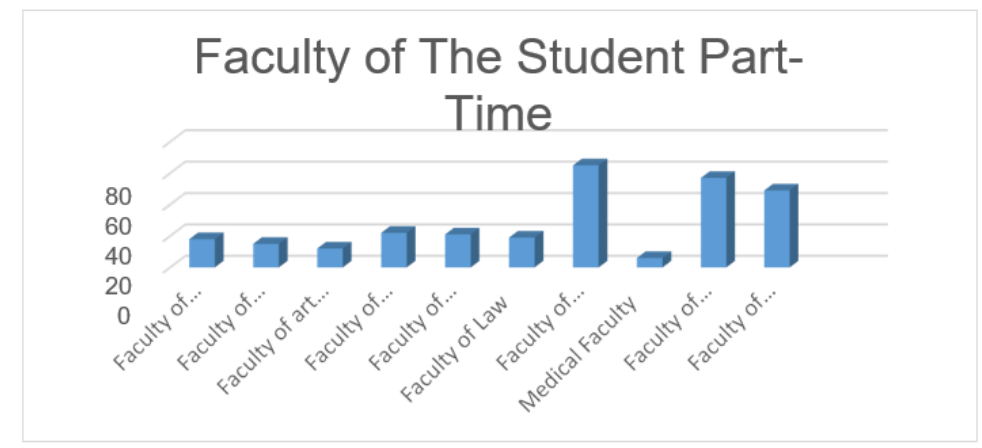

Pict 1. Faculty of The Student Part-Time

Based on Picture 1, the results obtained according to the grouping of undergraduate students of UNS who work part-time based on the Faculty, namely the Teaching and Education Faculty with 165 respondents or as much as $43 \%$ and the second most are from the Faculty of Mathematics and Natural Education, namely 57 respondents or as many $15 \%$.

\section{Type of Part-time Job}

Table I illustrates the type where students were working and shows that the majority of the sample was employed as an online shop, a tutors (private tutors, TPA/TPQteachers) an entrepreneurship, etc. 


\section{Type of Student Part-time Job}

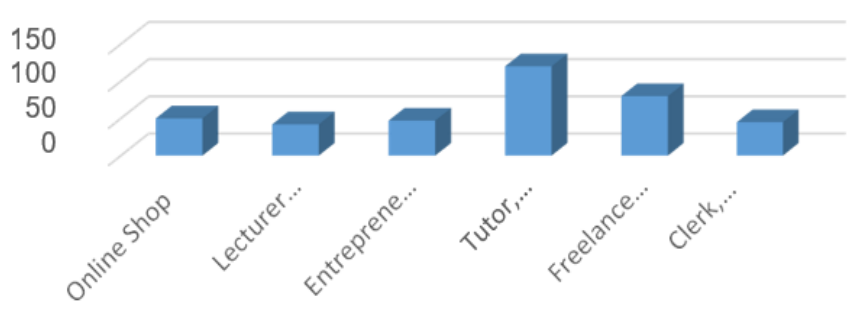

Picture 2. Type of Student Part-Time Job

From the table above it is known that 50 students or $13 \%$ of students answered that they work part-time as sellers of goods in online shops, 42 students or $11 \%$ of students answered that they work part-time as teaching assistants, practicum assistants, study program assistants. While 47 students or $12 \%$ of students answered that they work part- time as entrepreneurs who run their own businesses / owners and / or businesses of others, the largest percentage is 120 students or $31 \%$ of students answered that they work part- time as tutors, private tutors, and teachers. TPA / TPQ, then 80 students or $21 \%$ of students answered that they work part-time as freelance workers, including those who work as providers of online motorcycle taxis, food delivery services, video editing services, programmers. Meanwhile, other students answered that they work parttime as a sales assistant, waitress or outlet crew.

Table 1. Disadvantages and Advantages to Student of Working

\begin{tabular}{|l|l|c|}
\hline No. & \multicolumn{1}{|c|}{ Item } & $\begin{array}{c}\text { Yes } \\
\text { (\%) }\end{array}$ \\
\hline Disadvantages to Students of Working & \\
\hline 1. & I have less time to study & 4,8 \\
\hline 2. & Money needs take over from university & 6,5 \\
\hline 3. & $\begin{array}{l}\text { Tiredness from working means that I can't concentrate in } \\
\text { lessons. } \\
\text { Sometimes }\end{array}$ & 4,9 \\
\hline 4. & Increased stress & 4,7 \\
\hline 5. & Tiredness from work makes me late for lectures & 4,5 \\
\hline 6. & $\begin{array}{l}\text { I sometimes miss lessons altogether due to tiredness from } \\
\text { working }\end{array}$ & 4,1 \\
\hline 7. & $\begin{array}{l}\text { Work seems more important because I can see immediate } \\
\text { benefits }\end{array}$ & 5,7 \\
\hline 8. & The manager pressurises me to work longer & 4,2 \\
\hline 9. & $\begin{array}{l}\text { I don't see my friends so often and am not there when they are } \\
\text { discussing University work }\end{array}$ & 4,5 \\
\hline 10. & $\begin{array}{l}\text { Work seems more important because I spend more time there } \\
\text { than } \\
\text { in lectures }\end{array}$ & 4,5 \\
\hline Advantages to Students of Working & 7,5 \\
\hline 11. & Improves my ability to deal with people & 7,5 \\
\hline 12. & Improves my skills, such as communication skills \\
\hline 13. & It helps me to understand how a business is run & 7,4 \\
\hline 14. & Relieves stress about my financial situation & 7,3 \\
\hline
\end{tabular}




\begin{tabular}{|c|l|c|}
\hline 15. & Builds confidence & 7,4 \\
\hline 16. & I can relate subjects taught in lessons to what happens at work & 6,9 \\
\hline 17. & Enables me to organise my time more effectively & 7,3 \\
\hline \multicolumn{2}{|c|}{ TOTAL } & 100 \\
\hline
\end{tabular}

\section{Disadvantages to Students of Working}

It would appear that working does adversely affect various aspects of academic life and that working longer hours is associated with reduced academic performance. Tiredness, lack of time to study, increased stress, and the need for money are the main negative effects of working. These will affect study outside of the lecture room, but also it cannot be taken for granted that those present in lessons are concentrating fully. Learning is therefore affected within lectures as well as in students' own study time, where the increased stress and tiredness reported may impact on the ability to learn.

\section{Advantages to Students of Working}

The most important benefit for working students concerns the improvement of skills and the building up of confidence. Students with whom the questionnaire was piloted commented that the increased confidence transfers to university life in such things as speaking in class discussions and standing up at the front of the class to give a presentation.

\section{Consequences of working part time}

There is a continuing debate over whether combining full-time study and parttime employment is beneficial or detrimental to the individual. To explore this issue, participants were presented with a range of consequences experienced while working part-time identified by participants in previous studies, and asked to identify those outcomes that they had experienced.

The findings are interesting as they indicate that individuals who held a part-time job in this study experienced a greater number of "positive" effects derived from that employment that benefits to update the student's skill. These results would seem to be in agreement with much of the existing literature where similar findings were apparent. The following are some of the positive factors are achieved when students work part-time such as, the student can improve their communication skills through part-time work, part- time work improves their ability to build relationships with other people, working part- time helps student to build self-confidence, helps stundent to understand how to run a business, student to manage their time to be more effective in activities, helps student to reduce pressure of their financial condition, etc.

Tam and Morrison (Oi I \& Morrison, 2005) also report some benefits derived from part-time employment such as enhanced employability, while Manthei and Gilmore (Manthei \& Gilmore, 2005) found that students reported enhanced time management skills as a result of their work experiences. There are a considerable negative effect if the student works part-time with high working hours, which affects their learning achievement significantly, from an average overall value (before working part-time) of 3.57 and after working part-time to 3.48. In a qualitative study of student employment Moreau and Leatherwood (Moreau \& Leathwood, 2006) found that individuals holding a job always or usually found their academic studies "a struggle". This is similar to the findings of Carney (Carney et al., 2005) who concluded that the majority of those surveyed found their academic studies had been affected. In a study of student nurses Salamonson and Andrew (Salamonson \& Andrew, 2006) found that students who 
did not work had the highest scores in assessments, and that scores decreased as the amount of time spent in part-time employment increased. They also note, however, that academic performance can be affected by other factors. To investigate the impact of holding employment upon academic performance in more detail, the sample were asked if they felt they would have done better on assessments without a job. Of those who responded who felt they would indeed have performed better. It is evident that a reduction in leisure activities is the main outcome that arises from individuals holding a part-time job, followed by less time being spent on reading for their course.

This does, however, raise the somewhat contentious issue of the extent to which time for students to engage in leisure activities while at university is important. This impact on leisure time is supported by the findings of previous studies which have also reported similar outcomes [(Manthei \& Gilmore, 2005); (Ford et al., 1995); (Lindsay, R. and Paton-Saltzberg, R, 1996); (Van Dyke, R. and Little, B, 2002)]. The results here also indicate that part-time employment negatively affects some aspects of learning achievement, although to a lesser degree than social aspects. This presence of both negative and positive outcomes is supported by the findings of others, i.e. part-time employment whilst not being entirely negative, does incur some costs.

\section{FUTURE TRENDS AND CONCLUSIONS} follows:

Based on the results of the research and discussion above, it can be taken as

This paper set out to investigate the nature and composition of student part-time employment amongst higher education students through reporting the results of meet in people survey undertaken in a UNS Surakarta. The findings from the survey indicate that students continue to undertake part-time jobs during their studies and that they do so at a significant level. This adds further weight to the view that combining academic study with part-time employment continues to be a majority experience for students. A second key finding relates to the amount of time that individuals are spending in employment in comparison to time spent in the lecture room.

Our results provide evidence that there is an effect on academic studies of students taking paid employment during term-time. Fears that adverse effects increase with increasing number of hours worked do appear to be well founded. Nevertheless, working has been shown by this investigation to be beneficial to students in the enhancement of skills and confidence, and an increased understanding of how businesses are run.

In this department, working occupies roughly the same amount of the students' time as attending lectures, yet we persist in thinking of students as full-time. The increasing number of students working indicates that this trend to work whilst studying will continue, and the effects on the student experience need to be considered. The times of greatest pressure for students are during personal crises, and when coursework assignments are due to be handed in or the examination period is looming. These pressure points are exactly the same for part-time students as for full-time students.

If the benefits of working were more widely accepted and understood, the work could be integrated into the course, particularly for business studies and other 
SHEs: Conference Series 4 (3) (2021) 53-62

business-related courses. For any student, the enhanced time management skills, ability to deal with people and increased confidence are not only worth developing in themselves, but also transfer to the classroom. Also, a more systematic study of which skills develop through working and whether these are developed in a short time period, making it unnecessary to work long hours as far as skill development is concerned, would also be beneficial. 


\section{REFERENCES}

Barke, M., Braidford, P., Houston, M., Hunt, A., Lincoln, I., Morphet, C., \& Stone, I. (2000). Students in the Labour Market - Nature, Extent and Implications of TermTime Employment Among University of Northumbria Undergraduates. 215, 2-5.

Barron, P., \& Anastasiadou, C. (2009). Student part-time employment: Implications, challenges and opportunities for higher education. International Journal of Contemporary Hospitality Management, 21(2), 140-153. https://doi.org/10.1108/09596110910935642

Broadbridge, A., \& Swanson, V. (2005). Earning and learning: How term-time employment impacts on students' adjustment to university life. Journal of Education and Work, 18(2), 235-249. https://doi.org/10.1080/13639080500086008

Carney, C., McNeish, S., \& McColl, J. (2005). The impact of part time employment on students' health and academic performance: A Scottish perspective. Journal of Further and Higher Education, 29(4), 307-319. https://doi.org/10.1080/03098770500353300

Curtis, S., \& Shani, N. (2002). The effect of taking paid employment during term-time on students' academic studies. Journal of Further and Higher Education, 26(2), 129-138. https://doi.org/10.1080/03098770220129406

Darmody, M., \& Smyth, E. (2008). Full-time students? Term-time employment among higher education students in Ireland. Journal of Education and Work, 21(4), 349362. https://doi.org/10.1080/13639080802361091

Ford, J., Bosworth, D., \& Wilson, R. (1995). Part-time Work and Full-time Higher Education. Studies in Higher Education, 20(2), 187-202. https://doi.org/10.1080/03075079512331381693

Manthei, R. J., \& Gilmore, A. (2005). The effect of paid employment on university students' lives. Education and Training, 47(3), 202-215. https://doi.org/10.1108/00400910510592248

Mihail, D. M., \& Karaliopoulou, K. (2005). Greek university students: A discouraged workforce. Education and Training, 47(1), 31-39. https://doi.org/10.1108/00400910510580610

Moreau, M. P., \& Leathwood, C. (2006). Balancing paid work and studies: Working (class) students in higher education. Studies in Higher Education, 31(1), 23-42. https://doi.org/10.1080/03075070500340135

Oi I, B. T., \& Morrison, K. (2005). Undergraduate students in part-time employment in China. Educational Studies, 31(2), 169-180. https://doi.org/10.1080/03055690500095555

Salamonson, Y., \& Andrew, S. (2006). Academic performance in nursing students: Influence of part-time employment, age and ethnicity. Journal of Advanced Nursing, 55(3), 342-349. https://doi.org/10.1111/j.1365-2648.2006.03863_1.x

Winkler, I. (2009). Term-time employment: Exploring the influence of self-identity, motivation and social issues. Education and Training, 51(2), 124-138. https://doi.org/10.1108/00400910910941282 